\title{
Leaf anatomical features of three Theobroma species (Malvaceae s.l.) native to the Brazilian Amazon
}

\author{
Tarcymara Barata GARCIA ${ }^{1 *}$, Raimunda Conceição de Vilhena POTIGUARA², Tatiani Yuriko Souza \\ $\mathrm{KIKUCHI}^{2}$, Diego DEMARCO ${ }^{3}$, Ana Cristina Andrade de AGUIAR-DIAS ${ }^{4}$ \\ Museu Paraense Emílio Goeldi, Coordenação de Pesquisa e Pós-graduação, Av. Perimetral, 1901, 66077-530, Terra Firme, Belém, PA, Brazil. \\ Telefone/Fax: (91) 3075-6149 / (91) 3075-6268 \\ ${ }^{2}$ Museu Paraense Emílio Goeldi, Coordenação de Botânica, Av. Perimetral, 1901, 66077-530, Terra Firme, Belém, PA, Brazil. E-mail: typinheiro@yahoo.com.br \\ ${ }^{3}$ Universidade de São Paulo, Instituto de Biociências, Departamento de Botânica, Rua do Matão, 277, 05508-090, Caixa-Postal: 11461, Butantã, São Paulo, SP, Brazil. \\ E-mail: diegodemarco@usp.br \\ ${ }^{4}$ Universidade Federal do Pará, Instituto de Ciências Biológicas, Rua Augusto Corrêa, 1, 66075-110, Caixa-postal: 6109, Guamá, Belém, PA, Brazil. E-mail: acaaguiar@yahoo.com.br \\ * Corresponding author: tarcymara@gmail.com
}

\section{ABSTRACT}

Theobroma species have economic importance due to their use in the cosmetic and food industries, mainly in the production of chocolate. However, the anatomy of their vegetative structures remains poorly studied. The goal of this study was to describe the anatomical features of Theobroma grandiflorum, T. speciosum and T. subincanum to contribute to the biological knowledge of these species, as well as provide support to the biotechnological studies of native fruit plants of the Amazon. Leaves at different developmental stages were collected and analyzed under light microscopy and scanning electron microscopy. Sessile and stalked stellate trichomes and digitiform glandular trichomes were observed in the expanded leaves of T. grandiflorum and T. subincanum. These species were also similar in the morphology of the midrib, the organization of the mesophyll and the presence of starch grains in the midrib pith cells. Claviform glandular trichomes and mucilage cells in the epidermis occurred only in the expanded leaves of T. speciosum. The presence of mucilage secretory trichomes in shoot apices (colleters) of all species is a new finding for the genus Theobroma.

KEYWORDS: colleters, cupuassu, glandular trichomes, mucilage, stellate trichomes.

\section{Caracteres anatômicos foliares de três espécies de Theobroma (Malvaceae s.l.) nativas da Amazônia Brasileira}

\begin{abstract}
RESUMO
As espécies de Theobroma têm importância econômica devido a sua utilização nas indústrias cosmética e alimentícia, principalmente na produção de chocolate. Entretanto, a anatomia de suas estruturas vegetativas permanece pouco conhecida. $\mathrm{O}$ presente estudo teve por objetivo descrever as características anatômicas de Theobroma grandiflorum, T. speciosume T. subincanum, como contribuição ao conhecimento biológico dessas espécies, bem como, fornecer subsídios aos estudos biotecnológicos de fruteiras nativas da Amazônia. Folhas em diferentes estágios de desenvolvimento foram coletadas e analisadas sob microscopia de luz e eletrônica de varredura. Nas folhas expandidas de T. grandiflorum e T. subincanum foram observados tricomas dos tipos estrelado séssil, pedunculado e glandular digitiforme. Estas espécies também foram similares quanto à morfologia da nervura central, à organização do mesofilo e à presença de grãos de amido no parênquima medular da nervura central. Tricomas glandulares claviformes e células mucilaginosas na epiderme do limbo foliar ocorreram somente em T. speciosum. A presença de tricomas secretores de mucilagem nos ápices vegetativos (coléteres) de todas as espécies estudadas é um novo registro para o gênero Theobroma.
\end{abstract}

PALAVRAS-CHAVE: coléteres, cupuaçu, mucilagem, tricomas estrelados, tricomas glandulares. 


\section{INTRODUCTION}

The genus Theobroma L. (Malvaceae s.1.) includes 22 species distributed from the Amazon basin to southern Mexico (Cuatrecasas 1964, APG III 2009). In Brazil, it is represented by 13 species, all native to the Amazon (Esteves 2013). In this genus Theobroma cacao L. and T. grandiflorum (cupuassu) are the most economically important species, used, respectively, in the cosmetic and food industries, mainly in the production of chocolate and "cupulate" (a seed-derived product similar to chocolate). The seeds of $T$. grandiflorum have a juicy pulp with an acid-sweet flavor, which is used in the preparation of beverages, candies and ice creams (Venturieri 2011). Other species of the genus, such as T. speciosum (cacauí) and $T$. subincanum (cupuí) are not marketed, but their sweet pulp is consumed fresh and their seeds are used in the preparation of chocolate (Cuatrecasas 1964, Cavalcante 2010).

Theobroma grandiflorum is widely cultivated in northern Brazil, the largest production in the state of Pará, followed by Amazonas, Rondônia and Acre. However, the cultivation of this species is limited by insect pests and several fungal pathologies, mainly "witches' broom" (Crinipellis perniciosa (Stahel) Singer), which affects the vegetative and reproductive organs (Hanada et al. 2010).

The maintenance of the genetic diversity through germplasm collections, either in situ or ex situ, allows for the development of disease and pest resistant cultivars in addition to genetic breeding. Two in vivo collections of Theobroma are located in the state of Pará "George O'Neill Addison" and "Basil George David Bartley". These collections are essential for the in situ conservation of genetic resources since the seeds of Theobroma are recalcitrant, which limits the viability of conventional ex situ conservation (Silva et al. 2004).

The morphological and anatomical knowledge of Theobroma is important for the establishment and maintenance of germplasm collections, providing valuable information to breeding programs and agronomic studies regarding desirable attributes (Santos et al. 2012). Furthermore, the anatomical characters of Theobroma may provide useful information for phytopathological studies, contributing to the selection of disease resistant mother trees, mainly to combat witches' broom (Rio et al. 2008).

Although anatomical studies of this genus have recently been performed, most are related to seeds (Santos 2003, Martini et al. 2008), whereas the vegetative organs remain poorly investigated (Metcalfe and Chalk 1950, Nakayama et al. 1996, Ferreira et al. 2008). Therefore, the goal of the present study was to investigate the leaf anatomy of $T$. grandiflorum, T. speciosum and T. subincanum in order to contribute to the biological knowledge of species of Theobroma and provide support for the biotechnological studies of native fruit plants of the Amazon.

\section{MATERIALS AND METHODS}

\section{Plant material}

Expanded leaves were collected from Theobroma grandiflorum (Willd. ex Spreng) Schum., T. speciosum Willd. ex Spreng. and T. subincanum Mart. plants growing in the city of Moju, Pará, Brazil ( $\left.1^{\circ} 44^{\prime} S ; 48^{\circ} 30^{\prime} \mathrm{W}\right)$ and at the Estação de Recursos Genéticos do Cacau José Haroldo/ Comissão Executiva do Plano da Lavoura Cacaueira (ERJOH/ CEPLAC) ( $1^{\circ} 12^{\prime} \mathrm{S}$; $\left.49^{\circ} 13^{\prime} \mathrm{W}\right)$, located in the city of Marituba, Pará, Brazil. Voucher materials were deposited in the Joáo Murça Pires Herbarium at Museu Paraense Emílio Goeldi: T. grandiflorum (MG 200926, MG 196837), T. speciosum (MG 202760, MG 200901) and T. subincanum (MG 198499, MG 200900). Samples were selected from the third median of the petiole and the leaf blade from the fifth visible node. Vegetative shoot apices and non-expanded leaves were also collected for the analysis of the glandular trichomes.

\section{Light microscopy}

Samples were fixed in FAA (formalin, acetic acid, 70\% alcohol) for 24 h (Johansen 1940) or NBF (buffered neutral formalin) for $48 \mathrm{~h}$ (Lillie 1965), dehydrated in a tertiary butanol series and embedded in Paraplast (Johansen 1940). Transverse and paradermal sections (10-12 $\mu$ m thick) were cut on a rotatory microtome (RM 2245, Leica Biosystem Nussloch GmbH, Nussloch, Germany) and stained with astra blue (0,5\%) and safranin (1\%) (Gerlach 1984).

In addition, samples were fixed in $2.5 \%$ glutaraldehyde in $0.1 \mathrm{M}$ sodium phosphate buffer $\mathrm{pH} 7.2$ for $24 \mathrm{~h}$, dehydrated in an ethanol series and embedded in hydroxyethyl methacrylate (Leica-Historesin), following the manufacturer's recommendations. Then, sections $(8-10 \mu \mathrm{m})$ were stained with toluidine blue O, pH 6.8 (O'Brien et al. 1964). For epidermal analysis, leaf blade segments were dissociated using a hydrogen peroxide and acetic acid solution (Franklin 1945). Afterwards, epidermis were stained with astra blue $(0,5 \%)$ and safranin (1\%) (Gerlach 1984) and mounted in 50\% aqueous glycerin (Purvis et al. 1964).

Samples of both fixed and fresh material were submitted to histochemical tests using the following stains: periodic acid-Schiffs (PAS) reaction to identify total polysaccharides (McManus 1948), ruthenium red to detect mucilage (Gregory and Baas 1989), sudan black B to identify total lipids (Pearse 1985), and Lugol's solution to identify starch (Johansen 1940). Phenolic substances were detected through ferric chloride and by fixing fresh samples in a ferrous sulphate solution in formalin for $48 \mathrm{~h}$ (Johansen 1940). Photomicrographs were 
taken using a digital camera coupled to a light microscope (Axiolab, Zeiss, Jena, Germany).

\section{Scanning electron microscopy}

For scanning electron microscopy (SEM), the samples were fixed in $2.5 \%$ glutaraldehyde in $0.1 \mathrm{M}$ sodium phosphate buffer $\mathrm{pH} 7.2$ for $24 \mathrm{~h}$. They were then dehydrated in an ethanol series, critical-point dried using CO2, sputtered with gold (Robards 1978), and examined with a scanning electron microscope (Leo Electron Microscopy Ltd, 1450 VP, Cambridge, England).

\section{RESULTS}

\section{Leaf blade}

In surface view, the anticlinal walls of epidermal cells presented a slightly sinuous contour in $T$. grandiflorum and $T$. speciosum (Figures 1A, 1B) and were straight in T. subincanum (Figure 1C; Table 1). In all studied species, the epidermis was covered by a smooth cuticle layer with plate-like epicuticular wax deposits on the adaxial surface (Figure 1D). Abaxial surface had a dense indumentum (Figure 1E), mainly in $T$. subincanum (Figure 1F). All studied species had a leaf blade with a single-layered epidermis in cross section, with cells
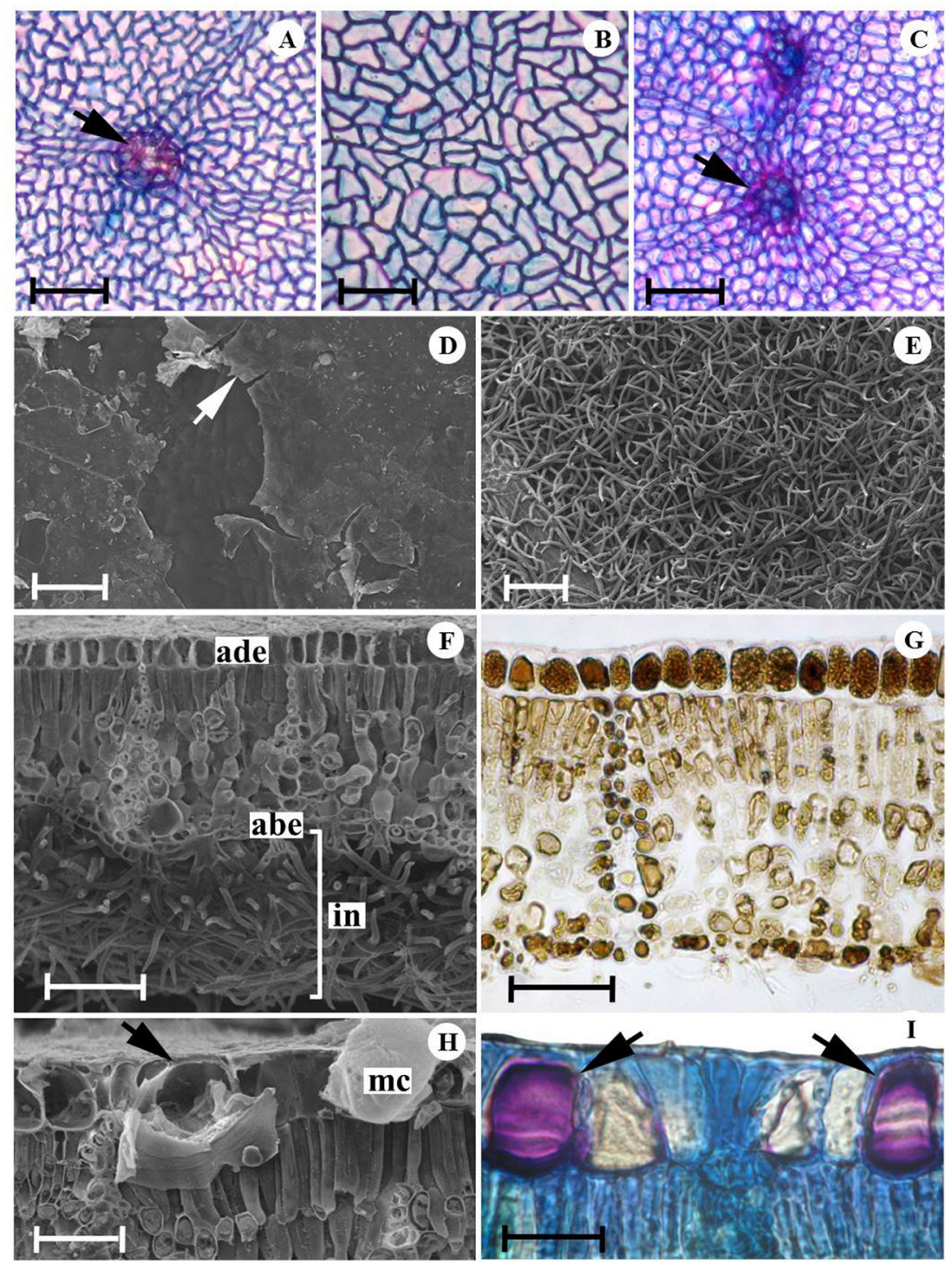

Figure 1. Epidermis of the leaf blade of $T$. grandiflorum (A, E, G), T. speciosum (B, D, H, I) and T. subincanum (C, F). A-D. Adaxial surface; black arrows indicate the basis of stalked stellate trichomes; note the smooth cuticle layer with plate-like epicuticular wax deposits (white arrow). E. Abaxial surface. F-I. Leaf blade in cross section showing a dense indumentum (F), epidermal cells containing phenolic compounds $(G)$ and mucilage idioblasts (arrows) in the adaxial surface (H, I). (abe: abaxial epidermis, ade: adaxial epidermis, in: indumentum, mc: mucilage). Scale bars $=50 \mu \mathrm{m}(\mathrm{A}-\mathrm{C}, \mathrm{F}), 40 \mu \mathrm{m}(\mathrm{D}, \mathrm{G}), 60 \mu \mathrm{m}(\mathrm{E}), 30 \mu \mathrm{m}(\mathrm{H}, \mathrm{I})$. This figure is in color in the electronic version. 
Table 1. Anatomical characters of leaf blade of T. grandiflorum, T. speciosum and T. subincanum. (+): present, (-): absent. (S1: leaf primordia and non-expanded leaves; S2: fully expanded leaves of fifth visible node).

\begin{tabular}{|c|c|c|c|}
\hline Character/Species & T. grandiflorum & T. speciosum & T. subincanum \\
\hline Epidermal anticlinal cell walls & Slightly sinuous & Slightly sinuous & Straight \\
\hline Mucilage idioblasts in the epidermis & - & + & - \\
\hline $\begin{array}{l}\text { Glandular trichome S1 } \\
\text { Size }(\mu \mathrm{m}) \\
\text { Secretory head (number of cells) } \\
\text { Stalk (number of cells) }\end{array}$ & $\begin{array}{l}\text { Clavate } \\
50-90 \\
7-12 \\
3-4\end{array}$ & $\begin{array}{l}\text { Clavate } \\
40-90 \\
5-10 \\
2-3\end{array}$ & $\begin{array}{l}\text { Clavate } \\
40-90 \\
6-7 \\
3-4\end{array}$ \\
\hline $\begin{array}{l}\text { Glandular trichome S2 } \\
\text { Size }(\mu \mathrm{m}) \\
\text { Secretory head (number of cells) } \\
\text { Stalk (number of cells) }\end{array}$ & $\begin{array}{l}\text { Digitiform } \\
30-35 \\
3-4 \\
2\end{array}$ & $\begin{array}{l}\text { Clavate } \\
30-35 \\
4-6 \\
2\end{array}$ & $\begin{array}{l}\text { Digitiform } \\
25-30 \\
2-3 \\
2\end{array}$ \\
\hline Stellate trichome & Sessile and stalked & Sessile & Sessile and stalked \\
\hline Spongy parenchyma cells & Isodiametric & Elongated & Isodiametric \\
\hline $\begin{array}{l}\text { Midrib } \\
\text { Cortical region (predominantly) } \\
\text { Starch grains in the pith }\end{array}$ & $\begin{array}{l}\text { Concave-convex } \\
\text { Sclerenchymatous + }\end{array}$ & $\begin{array}{l}\text { Biconvex } \\
\text { Parenchymatous } \\
\text { - }\end{array}$ & $\begin{array}{l}\text { Concave-convex } \\
\text { Parenchymatous } \\
+\end{array}$ \\
\hline
\end{tabular}

containing phenolic substances in both surfaces (Figure $1 \mathrm{G}$ ). Histochemical tests showed that in addition to phenolic cells, the adaxial epidermis of T. speciosum contained mucilage idioblasts (Figures 1H, 1I; Table 1).

Glandular and non-glandular trichomes were distributed on both surfaces of the expanded leaves of all species but they were more abundant on the abaxial surface (Figure 2A). Two morphological types of glandular trichomes were observed in this region: digitiform (Figures 2A, 2B), occurring on the leaf surface of $T$. grandiflorum and T. subincanum, and clavate (Figure 2C), occurring only on the leaf surface of T. speciosum. The two types of trichomes consisted of a basal cell, a bicellular stalk, and a multicellular secretory head (Table 1).

A number of clavate glandular trichomes (colleters) were also observed on both surfaces of leaf primordia (Figure 2D) and non-expanded leaves of all species (Figures 2E-H), but they differed from those described above by their size and cell number on the stalk and on the secretory head (Table 1). On the expanded leaves of the fifth visible node, only the basal region of these trichomes could be observed, indicating that they were deciduous. The secretion produced by these trichomes during the initial phases of leaf expansion was highly hygroscopic and viscous. In all species, PAS and ruthenium red reactions for polysaccharides and mucilage, respectively, were positive for the substances secreted by the head cells. The non-glandular trichomes were multicellular, stellate, four- to eight-armed, sessile (Figure 2I) or stalked (Figure 2J). The sessile stellate trichomes were abundant on the abaxial surface in all studied species, whereas the stalked stellate trichomes were exclusive to the veins on both leaf surfaces of the $T$. grandiflorum and T. subincanum (Table 1).

In cross section, the species had hypostomatic leaves with anomocytic stomata located above the other epidermal cells. The mesophyll in all species was dorsiventral with collateral vascular bundles surrounded by a sheath of sclerenchymatous and parenchymatous cells with phenolic content, which extended towards one or both surfaces (Figures 3A, 3B). The palisade parenchyma consisted of a single layer in $T$. speciosum, one to three layers in $T$. subincanum and $T$. grandiflorum. The spongy parenchyma was composed of three layers of transversally elongated cells in T. speciosum and three to five layers of isodiametric cells in T. subincanum and T. grandiflorum, respectively (Figures 3A, 3B; Table 1). Idioblasts containing calcium oxalate druses (Figure 3C) and prismatic crystals (Figure 3D) were observed among palisade parenchyma cells, particularly in T. subincanum and T. grandiflorum. 


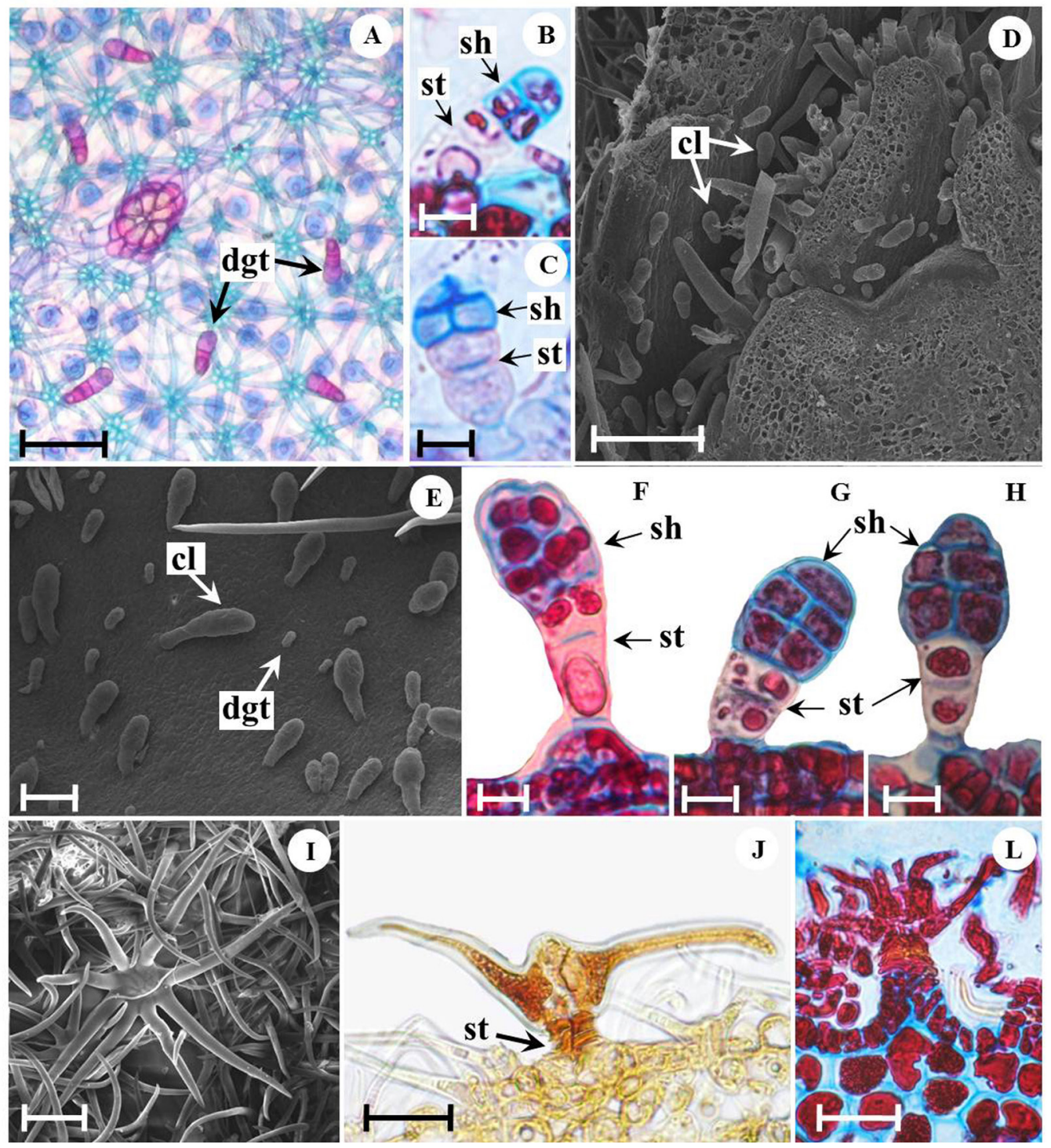

Figure 2. Trichomes on the leaves of T. grandiflorum (A, B, E, F), T. speciosum (C, G, I) and T. subincanum (D, H, J, L). A-C. Glandular trichomes on the expanded leaves, digitiform (A, B) and clavate (C). D-H. Glandular trichomes (colleters) on the leaf primordia (D) and non-expanded leaves (E), note a differentiating digitiform glandular trichome. I-J. Stellate trichomes on the leaf blade, sessile (I) and stalked (J). L. Stalked stellate trichome on the petiole (cl: colleters, dgt: digitiform, st: stalk, sh: secretory head). Scale bars $=50 \mu \mathrm{m}(\mathrm{A}, \mathrm{E}), 10 \mu \mathrm{m}(\mathrm{B}, \mathrm{C}, \mathrm{F}-\mathrm{H}), 100 \mu \mathrm{m}(\mathrm{D}), 30 \mu \mathrm{m}(\mathrm{I}, \mathrm{J}, \mathrm{L})$. This figure is in color in the electronic version.

In cross section, the leaf margins were revolute and had a rounded shape, thick cuticle, chlorenchyma consisting of isodiametric cells, and phenolic and crystal idioblasts in all of the species (Figure 3E). The midrib in cross section was biconvex in T. speciosum (Figure 3F) and concave-convex in the remaining species (Figures 3G, 3H; Table 1). In all of the species, two or three layers of angular collenchyma cells were located below the abaxial epidermis. Cortical region was composed predominantly of sclerenchymatous cells in T. grandiflorum (Figure 4A) and parenchymatous cells in $T$. subincanum and T. speciosum (Figure 4B). The vascular system of the midrib of all species was collateral, surrounded by a sclerenchymatous sheath (Figures $3 \mathrm{H}, 4 \mathrm{~A}$ ).

Cells containing phenolic compounds (Figure 4C) and crystals (prismatic and druses) were common in the dermal, vascular and ground tissue systems. Numerous starch grains were observed in the parenchyma cells of the midrib pith in T. grandiflorum and T. subincanum (Figure 4D; Table 1). Glands occurred both in the midrib cortex and pith (Figures 3F-H, 4B, 4D). The histochemical tests performed on these glands to detect total polysaccharides and mucilage showed positive results. However, lipophilic and phenolic substances were not identified. The anatomical characters of the leaf 

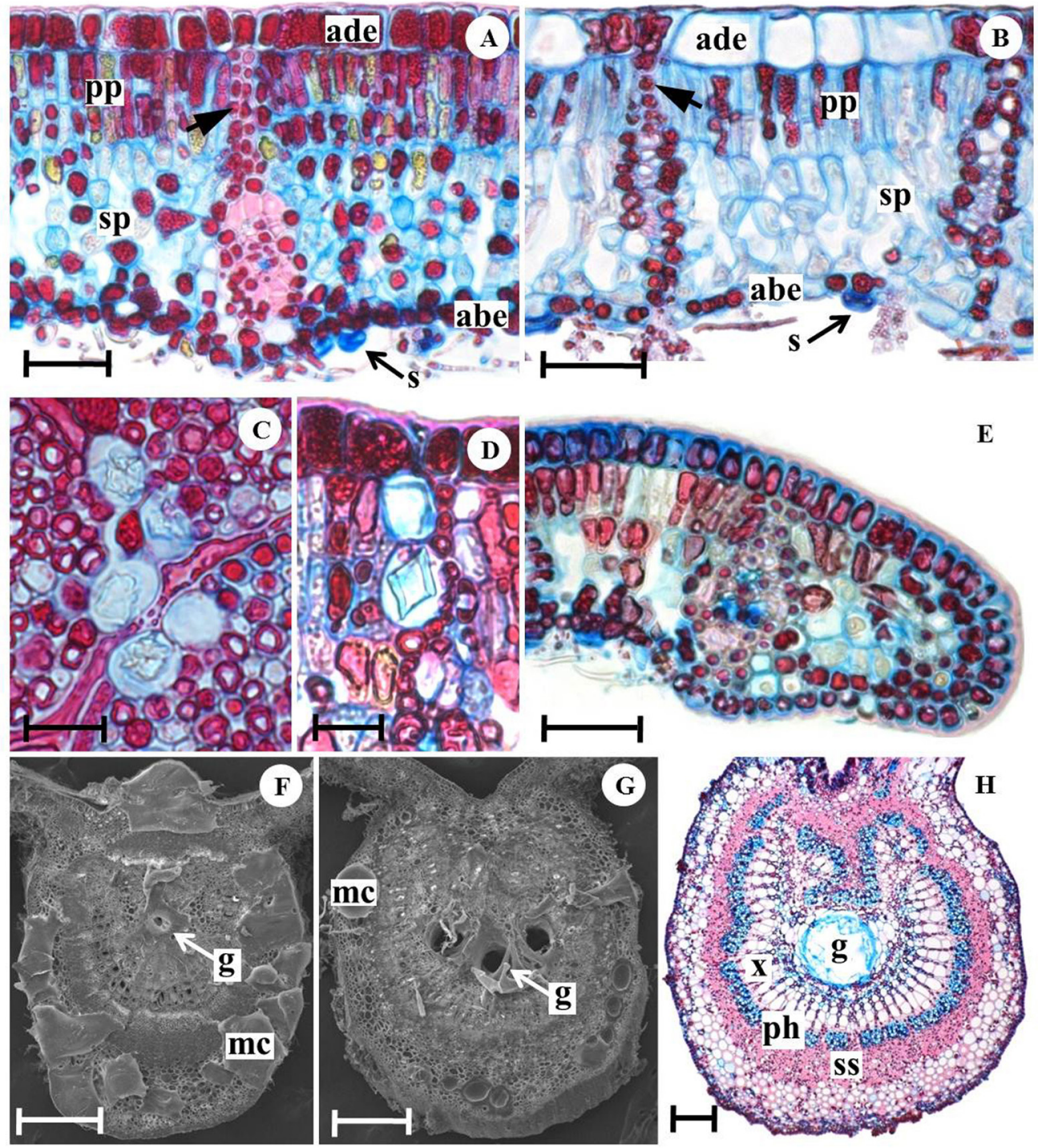

Figure 3. Mesophyll, margin and midrib of T. speciosum (A, F), T. grandiflorum (B, C-E, H) and T. subincanum (G) in cross section. A-B. Dorsiventral mesophyll, note the of sheath extensions bundles (arrows). C-D. Idioblasts containing calcium oxalate crystals in the mesophyll, druses (C) and prismatic (D). E. Margin. F-H. Midrib (abe: abaxial epidermis, ade: adaxial epidermis, g: gland, mc: mucilage, s: stomata, ph: phloem, pp: palisade parenchyma, sp: spongy parenchyma, ss: sclerenchymatous sheath, $\mathrm{X}$ : xylem). Scale bars $=40 \mu \mathrm{m}(\mathrm{A}-\mathrm{B}, \mathrm{E}), 20 \mu \mathrm{m}(\mathrm{C}, \mathrm{D}), 300 \mu \mathrm{m}(\mathrm{F}, \mathrm{G}), 200 \mu \mathrm{m}(\mathrm{H})$. This figure is in color in the electronic version.

blades of T. grandiflorum, T. speciosum and T. subincanum were summarized in Table 1 , where it was possible to verify the main similarities and differences among these species.

\section{Petiole}

The petiole of all studied species presented, in cross section, one layered epidermis with stomata located above the other epidermal cells (Figure 4E). The glandular and non-glandular trichomes were similar to those described for the leaf blade. The glandular trichomes were clavate and composed of a basal cell, two- or three-celled uniseriate stalk and a five- to ninecelled secretory head. The non-glandular trichomes could be sessile in $T$. speciosum and stalked in $T$. grandiflorum and $T$. subincanum (Figure 2L).

In addition, numerous idioblasts containing phenolic compounds and calcium oxalate crystals (prismatic and druses) occurred in the petiole cortex (Figures 4E, 4F). Druses were more numerous than prismatic crystals, mainly in $T$. subincanum. Mucilage glands, similar to those of the leaf blade were found in the petiole cortical (Figure 4F) and pith regions (Figure 4G). The vascular bundles of petiole were collateral in all studied species (Figure 4G). 

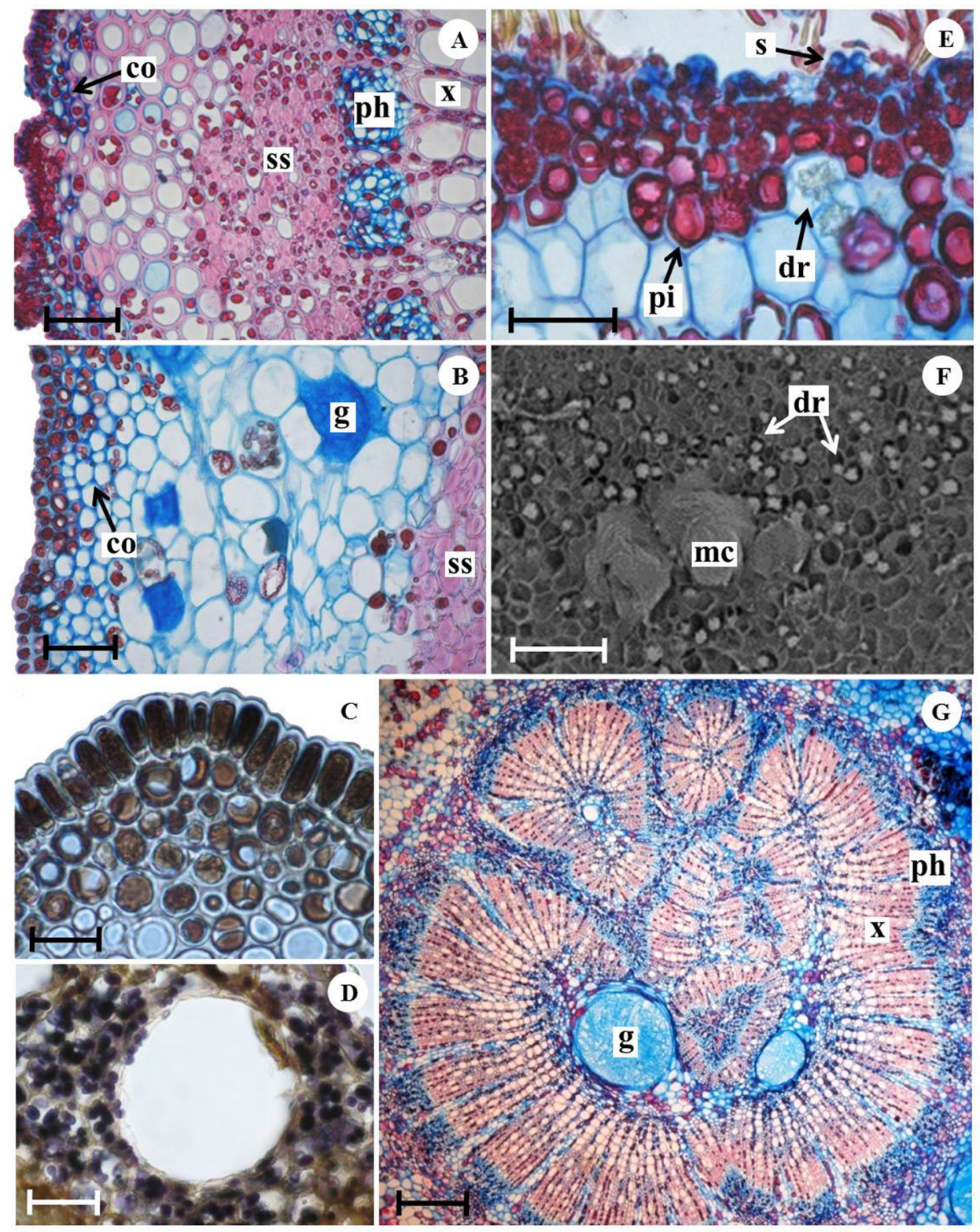

Figure 4. Midrib and petiole of T. grandiflorum (A, G), T. speciosum (B, C, E, F) and T. subincanum (D) in cross section. A-D. Midrib showing cortical region $(A, B)$, cells with phenolic compounds in the epidermis (C) and starch grains in the pith (D). E-G. Petiole showing cortex (E, F) and vascular system (G). (co: collenchyma, dr: druses, g: gland, mc: mucilage, ph: phloem, pi: phenolic idioblast, s: stomata, ss: sclerenchymatous sheath, $x: x y l e m)$. Scale bars $=50 \mu \mathrm{m}$ $(\mathrm{A}, \mathrm{B}, \mathrm{E}, \mathrm{D}), 20 \mu \mathrm{m}(\mathrm{C}), 200 \mu \mathrm{m}(\mathrm{F}), 300 \mu \mathrm{m}(\mathrm{G})$. This figure is in color in the electronic version.

\section{DISCUSSION}

The leaf anatomical features examined in the present study are in accordance with those previously described for Sterculiaceae (currently circumscribed in Malvaceae s.l.) regarding the vascular structure of petiole, stomatal type and distribution, presence of crystals usually in form of druses, mucilage-secreting structures, and stellate trichomes (Metcalfe and Chalk 1950). The last two characteristics are synapomorphies of Malvaceae s.l. (APG III 2009).
The studied species are characterized by a dense indumentum consisting of glandular and non-glandular trichomes. The morphological variation and distribution of these trichomes on the leaf surface are useful characters for the subgeneric classification in Malvaceae s.l., as reported for Mortoniodendron Standl. \& Steyerm. (Rédon-Carmona et al. 2006), Abutilon Mill. (Shaheen et al. 2009a), Hibiscus L. (Shaheen et al. 2009b), Sida L. (Shaheen et al. 2009c), and in the present study for Theobroma. 
To date, glandular trichomes in Theobroma are reported only for T. cacao (Nakayama et al. 1996). We are describing for the first time the presence of glandular trichomes in $T$. grandiflorum, T. speciosum and T. subincanum. In these species, although the trichomes found in the vegetative shoot apices are homologous to those of expanded leaves, they may play a different role. In the vegetative shoot apices, these trichomes are abundant, with a well developed secretory head, whose mucilage secretion may provide lubrication and protection against desiccation during early stages of leaf development. According to Paiva and Martins 2011, structures with this morphology are similar to colleters. In the family Malvaceae s.l. colleters are reported only in Hibiscus pernambucensis Arruda and H. tiliaceus L. (Rocha et al. 2002).

Leaf trichomes may be an effective defense mechanism in plants. They may be involved in both chemical and mechanical defense, negatively affecting the oviposition rate and feeding of herbivorous insects and nutrition of larvae (Lokesh and Singh 2005). It is possible that the leaf trichome density in the studied species can play a role in protection against herbivores insects, which are considered pests in the cultivation of some species of this genus, such as beetle (Barbosa and Fonseca 2002), caterpillar (Lourido et al. 2007), and leaf-cutting ants (Delabie 1989). However, additional studies are needed to better understand the ecological role of these trichomes in Theobroma.

The occurrence of mucilaginous cells in the leaf epidermis is described in 69 families of eudicotyledons including Malvaceae s.l. (Metcalfe and Chalk 1950). In the present study, T. speciosum is the only species to present mucilaginous cells in the leaf epidermis. However, these mucilaginous cells are observed only on the adaxial surface of the leaf blade, a feature also reported in other representatives of Malvaceae s.l., such as T. cacao L. (Nakayama et al. 1996), Dombeya Desf. and Nesogordonia Baill. (Lersten and Curtis 1997), Sterculia Vent. (Hussin and Sani 1998), Hibiscus (Rocha et al. 2002) and Pavonia alnifolia A.St.-Hil. (Pimentel et al. 2011).

Another important feature found in the species examined for this study is the presence of numerous calcium oxalate crystals, mainly in the form of druses. Calcium oxalate crystals in plants are involved in several physiological functions and may play an ecological role as static or active defense structures (Franceschi and Nakata 2005). Their synthesis not only depends on calcium levels but can also be influenced by external pressures such as herbivory. For example, in Sida rhombifolia L. (Malvaceae), herbivory increases the synthesis of crystals in seedling leaves even if calcium availability is limited (Molano-Flores 2001).

Cells with phenolic content also have a wide distribution on leaf tissues of the species studied here. A previous study has shown that phenolic compounds in T. cacao have an inhibitory effect on Crinipellis perniciosa basidiospores germination, representing a mechanism of resistance to witches' broom disease (Nojosa et al. 2003). The presence of crystals and phenolic idioblasts in the leaves of Theobroma species may thus have a protective function against herbivory and may increase the resistance to witches' broom disease.

\section{CONCLUSION}

We have verified that T. grandiflorum and T. subincanum share the presence of digitiform glandular trichomes, stalked and sessile stellate trichomes, isodiametric cells in the spongy parenchyma, a concave-convex midrib, and starch grains in the midrib pith cells, while T. speciosum presents clavate glandular trichomes, only sessile stellate trichomes, elongated cells in the spongy parenchyma, a biconvex midrib, and mucilaginous cells in the epidermis. Such characteristics provide a useful tool for taxonomic studies of the species of Theobroma. We have evidenced that the presence of mucilage secretory trichomes in shoot apices (colleters) of all species is a new finding for this genus.

\section{ACKNOWLEDGEMENTS}

The first author is grateful to the Conselho Nacional de Desenvolvimento Científico e Tecnológico (CNPq) for a graduate student scholarship (Process number 132764/20105) and to the Programa de Pós-Graduação em Ciências Biológicas - Botânica Tropical of the Museu Paraense Emílio Goeldi and Universidade Federal Rural da Amazônia. We also greatly acknowledge the Comissão Executiva do Plano da Lavoura Cacaueira (CEPLAC) for providing equipment and technical support and Dr Dewey Litwiller (University of Saskatchewan, Saskatoon, Saskatchewan, Canada) for the revision of the paper and value suggestions and comments.

\section{REFERENCES}

APG III. 2009. An update of the Angiosperm Phylogeny Group classification for the orders and families of flowering plants: APG III. Botanical Journal of the Linnean Society, 161: 105-121.

Barbosa, M.G.V.; Fonseca, C.R.V. 2002. Coleopterofauna visitante de Theobroma grandiflorum Schum. (Sterculiaceae) de uma plantação nos arredores de Manaus, Amazonas, Brasil. Acta Amazonica, 32: 83-100.

Cavalcante, P. 2010. Frutas comestiveis na Amazônia. 7th ed. Belém: Museu Paraense Emílio Goeldi, 282 p.

Cuatrecasas, J. 1964. Cacao and its allies: a taxonomic revision of the genus Theobroma. Contributions from the United States National Herbarium, 35: 379-614.

Delabie, J.H.C. 1989. Novas opçóes para controle das formigas cortadeiras Acromyrmex subterraneus brunneus e Atta sexdens sexdens (Hymenoptera: Formicidae: Attini), na regiáo cacaueira da Bahia, Brasil. Revista Agrotrópica, 1: 173-180. 
Esteves, G. 2013. Theobroma. In: Lista de Espécies da Flora do Brasil. Jardim Botânico do Rio de Janeiro. (www.floradobrasil.jbrj.gov. br/jabot/floradobrasil/FB156). Acesso em 12/08/2013.

Ferreira, M.G.R.; Nogueira, A.E.; Damião-Filho, C.F. 2008. Morfologia foliar de Theobroma grandiflorum Schum. Ciência Rural, 38: 530-533.

Franceschi, V.R; Nakata, P.A. 2005. Calcium oxalate in plants: formation and function. Annual Review of Plant Biology, 56: 41-71.

Franklin, G.L. 1945. Preparation of thin sections of synthetic resins and wood-resin composites, and a new macerating method for wood. Nature, 155: 51.

Gerlach, D. 1984. Botanische Mikrotechnik: eine einfuhrung. Georg Thieme, Stuttgart, $311 \mathrm{p}$.

Gregory, M.; Baas, P. 1989. A survey of mucilage cells in vegetative organs of the dicotyledons. Israel Journal of Botany, 38: 125-174.

Hanada, R.E.; Pomella, A.W.V.; Costa, H.S.; Bezerra, J.L.; Loguercio, L.L.; Pereira, J.O. 2010. Endophytic fungal diversity in Theobroma cacao (cacao) and T. grandiflorum (cupuaçu) trees and their potential for growth promotion and biocontrol of black-pod disease. Fungal Biology, 114: 901-910.

Hussin, K.H.; Sani, Z.M. 1998. Comparative leaf anatomical studies of some Sterculia L. species (Sterculiaceae). Botanical Journal of the Linnean Society, 127: 159-174.

Johansen, D.A. 1940. Plant Microtechnique. McGraw-Hill, New York, $523 \mathrm{p}$.

Lersten, N.R.; Curtis, J.D. 1997. Leaf anatomy of Dombeya and Nesogordonia (Sterculiaceae), emphasizing epidermal and internal idioblasts. Plant Systematics and Evolution, 207: 59-86.

Lillie, R.D. 1965. Histopathologic Technic and Practical Histochemistry. McGraw Hill, New York, 1024 p.

Lokesh; Singh, R. 2005. Influence of leaf vein morphology in okra genotypes (Malvaceae) on the oviposition of the leafhopper species Amrasca biguttula (Hemiptera: Cicadellidae). Entomologia Generalis, 28: 103-114.

Lourido, G.; Silva, N.M.; Motta, C. 2007. Parâmetros biológicos e injúrias de Macrosoma tipulata Hübner (Lepidoptera: Hedylidae), em cupuaçuzeiro [Theobroma grandiflorum (Wild ex Spreng Schum)] no Amazonas. Neotropical Entomology, 36: 102-106.

Martini, M.H.; Lenci, C.G.; Figueira, A.; Tavares, D.Q. 2008. Localization of the cotyledon reserves of Theobroma grandiflorum (Willd. ex Spreng.) K. Schum., T. subincanum Mart., T. bicolor Bonpl. and their analogies with T. cacao L. Brazilian Journal of Botany, 31: 147-154.

McManus, J.F.A. 1948. Histological and histochemical uses of periodic acid. Stain Technology, 23: 99-108.

Metcalfe, C.R.; Chalk, L. 1950. Anatomy of the dicotyledons: Leaves, stem and wood in relation to taxonomy with notes on economic uses. Clarendon Press, Oxford, 1500 p.

Molano-Flores, B.M. 2001. Herbivory and calcium concentrations affect calcium oxalate crystal formation in leaves of Sida (Malvaceae). Annals of Botany, 88: 387-391.
Nakayama, L.H.I.; Soares, M.K.M.; Appezzato-da-Glória, B. 1996. Contribuição ao estudo anatômico da folha e do caule do cacaueiro (Theobroma cacao L.). Scientia Agricola, 53: 73-73.

Nojosa, G.B.A; Resende, M.L.V.; Aguilar, M.A.G.; Bezerra, K.M.T; Anhert, D.E. 2003. Componentes fenólicos e enzimas oxidativas em clones de Theobroma cacao resistentes e suscetíveis a Crinipellis perniciosa. Fitopatologia Brasileira, 28: 148-154.

O’Brien, T.P.; Feder, N.; Mccully, M.E. 1964. Polychromatic staining of plant cell walls by toluidine blue O. Protoplasma, 59: 368-373.

Paiva, E.A.S.; Martins, L.C. 2011. Calycinal trichomes in Ipomoea cairica (Convolvulaceae): ontogenesis, structure and functional aspects. Australian Journal of Botany, 59: 91-98.

Pearse, A.G.E. 1985. Histochemistry theoretical and applied. C. Livingstone, Edinburgh, Scotland, 634 p.

Pimentel, R.R.; Machado, S.R.; Rocha, J. F. 2011. Estruturas secretoras de Pavonia alnifolia (Malvaceae), uma espécie ameaçada de extinção. Rodriguésia, 62: 253-262.

Purvis, M.J.; Collier, D.C.; Walls, D. 1964. Laboratory Techniques in Botany. Butterwoths, London, $371 \mathrm{p}$.

Rédon-Carmona, N.; Ishiki-Ishihara, M.; Terrazas, T.; Nieto-López, M.G. 2006. Indumento y tricomas en la caracterización de un grupo de nueve especies del género Mortoniodendron (Tiliaceae). Revista Mexicana de Biodiversidad, 77: 169-176.

Rio, M.C.S.; Oliveira, B.V.; Tomazella, D.P.T.; Silva, J.A.F.; Pereira, G.A.G. 2008. Production of calcium oxalate crystals by the basidiomycete Moniliophthora perniciosa, the causal agent of witches' broom disease of cacao. Current Microbiology, 56: 363-370.

Robards, A.W. 1978. An introduction to techniques for scanning electron microscopy of plant cells. In: J. L. Hall (ed.), Electron Microscopy and Cytochemistry of Plant Cells. Elsevier, New York, p. 343-403.

Rocha, J.F.; Neves, L.J.; Pace, L.B. 2002. Estruturas secretoras em folhas de Hibiscus tiliaceus L. e Hibiscus pernambucensis Arruda. Revista Universidade Rural, 22: 43-55.

Santos, S.F. 2003. Estrutura e histoquimica de sementes do gênero Theobroma L. (Sterculiaceae). Dissertação de Mestrado. Universidade Federal de Santa Catarina, Florianópolis, SC.

Santos, R.C.; Pires, J.L.; Correa, R.X. 2012. Morphological characterization of leaf, flower, fruit and seed traits among Brazilian Theobroma L. species. Genetic Resources and Crop Evolution, 59: 327-345.

Shaheen, N.; Khan, M.A.; Yasmin, G.; Hayat, M.Q., Ahmad, M.; Zafar, M.; Jabeen, A. 2009a. Implication of foliar epidermal features in the taxonomy of Abutilon Mill. (Malvaceae). Journal of Medicinal Plant Research, 3: 1002-1008.

Shaheen, N.; Ajab, M.; Yasmin, G.; Hayat, M.Q. 2009b. Diversity of foliar trichomes and their systematic relevance in the genus Hibiscus (Malvaceae). International Journal of Agriculture and Biology, 11: 279-284.

Shaheen, N.; Khan, M.A.; Yasmin, G.; Ahmad, M.; Mahmood, T.; Hayat, M. Q.; Zafar, M. 2009c. Foliar epidermal anatomy and its systematic implication within the genus Sida L. (Malvaceae). African Journal of Biotechnology, 8: 5328-5336. 
Silva, C.R.S.; Venturieri, G.A.; Figueira, A. 2004. Description of Amazonian Theobroma L. collections, species identification, and characterization of interspecific hybrids. Acta Botanica Brasilica, 18: 333-341.

Venturieri, G.A. 2011. Flowering levels, harvest season and yields of cupuassu (Theobroma grandiflorum). Acta Amazonica, 41: 143-152.

Recebido em 18/02/2013

Aceito em 13/09/2013 